\title{
PELATIHAN JARIMATIKA SEBAGAI CARA MUDAH MENGHAFAL PERKALIAN DASAR DI UPT SPF SDN 124 BATUASANG
}

\author{
Erni Ekafitria Bahar ${ }^{*}$ \\ Andi Alim Syahri² \\ 1,2Prodi Pendidikan Matematika Universitas Muhammadiyah Makassar, Makassar, Indonesia \\ erniekafitria@unismuh.ac.id ${ }^{*}{ }^{*}$ \\ andialims@unismuh.ac.id $\left.{ }^{2}\right)$
}

Kata Kunci:
[Jarimatika, Perkalian
Dasar Usaha]

Published by:

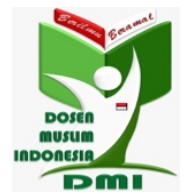

Copyright (C) 2021 The Author(s)

This article is licensed under CC BY 4.0 License
Abstrak: Kegiatan pengabdian kepada masyarakat (PKM) ini bertujuan untuk memberikan pengetahuan kepada peserta tentang perkalian dengan menggunakan jarimatika sehingga mereka lebih mudah menghafal perkalian dasar. Kegiatan ini hanya memperkenalkan penggunaan jarimatika pada perkalian 1 sampai 9. Metode yang digunakan yaitu: (1) Metode observasi untuk mengumpulkan data tentang kemampuan perkalian peserta didik, (2) Metode ceramah dan demonstrasi dilakukan pada saat menyajikan materi, (3) Metode pemberian angket untuk mengetahui respon peserta selama kegiatan pelatihan. Peserta kegiatan sebanyak 20 orang yang merupakan peserta didik kelas IV sampai VI. Peserta pelatihan antusias selama kegiatan ini. Hasil pengabdian ini adalah: (1) peserta didik memahami formasi jari tangan dan aturan perkalian dengan menggunakan jarimatika; (2) peserta didik merasa lebih mudah dan lebih cepat dalam menghitung perkalian dasar dengan menggunakan jarimatika; (3) peserta didik memberikan respon positif (75\%) terhadap kegiatan pelatihan ini. Pelatihan ini mempermudah peserta didik menghafal perkalian dengan menggunakan jari tangan tanpa harus menghafal dengan meted konvensional.

\section{(cc) BY}

https://dmi-journals.org/jai/ 


\section{Pendahuluan}

Pendidikan merupakan salah satu faktor yang menentukan kemajuan suatu negara. Pendidikan adalah dasar dari proses untuk manusia mengembangkan potensi yang ada pada dirinya sehingga dapat beradaptasi dengan perubahan yang terjadi. Menurut (Syah, 2010) bahwa pendidikan berasal dari kata dasar "didik" yang mempunyai arti memelihara dan memberi latihan. Bentuk nyata proses pendidikan yang dijalani siswa di sekolah tercermin dalam proses pembelajaran di kelas. Sehingga pendidikan merupakan sarana untuk meningkatkan kualitas hidup manusia secara berkelanjutan yang diharapkan mampu memberi bekal kemampuan menerapkan pengetahuannya dalam kehidupan sehari-hari.

Salah satu pengetahuan dalam pendidikan yang mampu mengembangkan daya pikir manusia adalah pengetahuan matematika. Matematika merupakan pengetahuan universal yang mendasari perkembangan teknologi modern, mempunyai peranan penting dalam berbagai disiplin ilmu dan mengembangkan daya pikir manusia. Pentingnya matematika untuk dipelajari menyebabkan matematika menjadi salah satu bidang studi yang dipelajari pada setiap jenjang pendidikan baik tingkat dasar, menengah maupun perguruan tinggi.

Matematika menjadi salah satu mata pelajaran yang diajarkan di sekolah-sekolah dengan frekuensi jam pelajaran yang lebih banyak dibandingkan mata pelajaran lain. Namun banyak yang menganggap bahwa pelajaran matematika merupakan pelajaran yang sulit dan menjadi momok bagi sebagian peserta didik. Hal inilah yang menjadi salah satu penyebab rendahnya hasil belajar matematika peserta didik.

Salah satu peningkatan mutu matematika yaitu dengan mempelajari hal yang mendasar dalam matematika (Jana \& Rahmawan, 2019). Keterampilan dasar adalah standar minimal bagi peserta didik di Pendidikan dasar untuk melanjutkan ke Pendidikan menengah. Salah satu keterampilan dasar yang harus dimiliki peserta didik pada jenjang sekolah dasar adalah perkalian. Materi perkalian diperkenalkan kepada peserta didik pada jenjang kelas III SD. Materi ini sangat penting karena merupakan prasyarat untuk mempelajari materi berhitung selanjutnya. Umumnya siswa sekolah dasar diwajibkan menghafal perkalian dasar yaitu perkalian bilangan dari 1 sampai 9. Hal ini karena perkalian dasar tersebut akan digunakan peserta didik hingga tingkat perguruan tinggi. Namun, yang menjadi masalah adalah sebagian peserta didik masih belum menghafal perkalian dasar tersebut.

Berdasarkan observasi awal pada sekolah mitra, hasil wawancara beberapa guru kelas menunjukkan bahwa sebagian besar peserta didik belum menghafal perkalian dasar. Guru kelas sudah memberikan daftar perkalian untuk dihafalkan, namun masih banyak yang belum mampu menghafal. Kondisi pandemi yang mengharuskan study from home (belajar dari rumah) membuat guru kesulitan untuk mengecek sampai sejauh mana peserta didik sudah mampu menguasai perkalian dasar. Hal ini karena pembelajaran online tidak berjalan lancar yang disebabkan minimnya penguasaan peserta didik dalam menggunakan aplikasi daring dan juga lemahnya jaringan internet di lokasi sekolah mitra. Selain itu, tidak semua peserta didik memiliki android yang dapat mendukung pembelajaran online. Sehingga diperlukan suatu metode untuk memudahkan peserta didik dalam menghafal perkalian dasar. Dalam hal ini pengabdi akan memberikan pelatihan secara langsung yaitu tentang penggunaan jarimatika. Jarimatika merupakan singkatan dari jari dan matematika yaitu cara berhitung matematika untuk anak-anak 
dengan menggunakan jari tangan yang dikembangkan oleh Septi Peni Wulandani. Wulandani (2008) mengungkapkan bahwa jarimatika adalah teknik berhitung mudah dan menyenangkan.

Tujuan pengabdian ini adalah agar peserta didik memperoleh pengetahuan tentang perkalian dengan menggunakan jarimatika sehingga mereka lebih mudah menghafal perkalian dasar. Kegiatan pengabdian ini hanya memperkenalkan penggunaan jarimatika pada perkalian 1 sampai 9. Manfaat kegiatan ini adalah peserta didik dapat dengan mudah mengahafal perkalian dasar dengan menggunakan jari tangan tanpa harus menghafal dengan metode konvensional.

\section{Metode Pelaksanaan}

Pengabdian dilaksanakan di UPT SPF SDN 124 Batuasang, Desa Singa, Kecamatan Herlang Bulukumba pada tanggal 29 April 2021. Kegiatan ini dilakukan secara langsung (tatap muka) dengan memperhatikan protokol kesehatan. Sasaran kegiatan ini adalah peserta didik kelas IV sampai VI pada sekolah mitra. Penentuan peserta didik yang akan mengikuti pelatihan atau pembinaan ini dilakukan dengan terlebih dahulu meminta data dari sekolah mengenai peserta didik dan pertimbangan guru serta kesedian orang tua untuk memberikan izin kepada anaknya mengingat pengabdian ini dilaksanakan pada masa pandemi.

Metode yang digunakan pada kegiatan ini antara lain: (1) Metode observasi, dilakukan dengan melakukan wawancara terhadap guru kelas untuk mengumpulkan data tentang kemampuan perkalian peserta didik, (2) Metode ceramah dan demonstrasi dilakukan pada saat menyajikan materi jarimatika, (3) Metode pemberian angket dilakukan setelah penyampaian materi untuk mengetahui respon peserta didik selama kegiatan pelatihan.

Kegiatan pengabdian yang dilaksanakan terbagi menjadi tiga tahap utama, yaitu tahap persiapan, tahap pelaksanaan dan tahap evaluasi. Kegiatan yang dilakukan pada tahap persiapan antara lain: (a) melakukan survey dan observasi pada lokasi dan sasaran, (b) berkoordinasi dengan kepala sekolah sebagai tempat dilaksanakannya kegiatan pengabdian, (c) Menyusun bahan materi pelatihan. Tahap pelaksanaan dilakukan setelah tahap persiapan selesai. Pada tahap pelaksanaan dilakukan kegiatan pelatihan yaitu dengan memberikan penjelasan tentang cara menentukan hasil kali dua bilangan dengan menggunakan jarimatika. Tahap evaluasi dilakukan setelah tahap pelaksanaan. Kegiatan yang dilakukan adalah pemberian angket kepada peserta didik yang menjadi peserta pelatihan untuk mengetahui atau mengukur respon peserta setelah mengikuti pelatihan. Indikator keberhasilan kegiatan ini adalah apabila 75\% peserta didik memberikan respon positif terhadap kegiatan ini berdasarkan angket yang dibagikan. Selain itu, kemampuan peserta didik dalam menentukan hasil kali dua bilangan juga diharapkan meningkat. Hal ini dapat dilihat pada saat proses tanya jawab setelah pemberian materi.

\section{Hasil dan Pembahasan}

Pelatihan jarimatika ini dilaksanakan sesuai dengan jadwal yang telah ditentukan dengan teknis pelaksanaan adalah pelatihan secara langsung (tatap muka) dengan tetap mematuhi protokol kesehatan. Pelatihan ini mampu memberikan pengetahuan dasar kepada peserta didik tentang bagaimana menentukan hasil perkalian dua buah bilangan dengan mnggunakan jari-jari tangan. Sebelum kegiatan pengabdian dilaksanakan, 
pengabdi berkoordinasi dengan pihak sekolah mitra atau kepada Kepala Sekolah meminta data-data peserta didik kelas IV sampai VI. Pengabdi melakukan observasi terkait kemampuan peserta didik dalam hal perkalian dasar. Observasi ini dilaksanakan dengan cara mewawancarai guru kelas. Selanjutnya pengabdi menyeleksi beberapa peserta didik dari masing-masing kelas untuk mengikuti pelatihan ini dan membagikan surat pernyataan izin dari orang tua. Banyaknya peserta didik yang mengikuti pelatihan ini adalah 20 orang yang terdiri dari 6 orang peserta didik kelas IV, 6 orang kelas V, dan 8 orang kelas VI. Dalam rangka persiapan pelatihan, maka hal-hal yang dipersiapkan pengabdi adalah materi pelatihan dan juga angket respon peserta didik terhadap pelaksanaan pelatihan.

Tahap pelaksanaan dilakukan setelah seluruh tahap persiapan selesai. Pelaksanaan pelatihan diawali pembukaan oleh kepala sekolah mitra. Pada tahap ini pengabdi memberikan penjelasan mengenai cara menentukan hasil kasil dua bilangan dengan menggunakan jari.

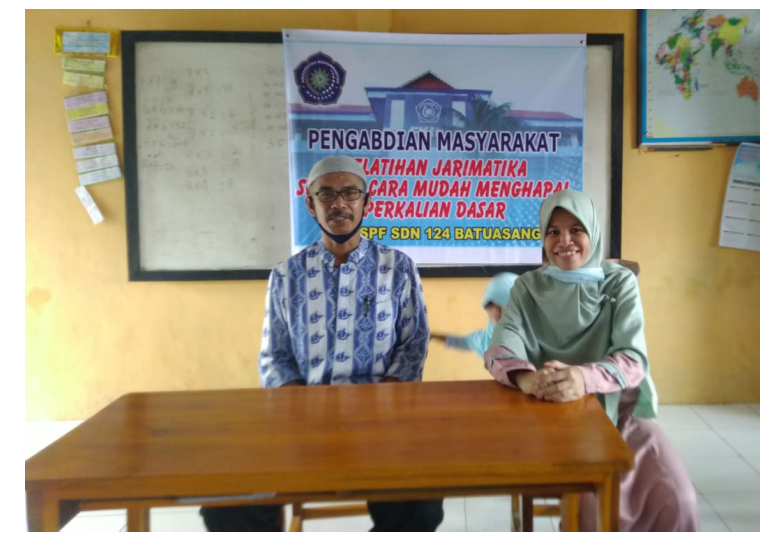

Gambar 1. Pembukaan Pelatihan Oleh Kepala Sekolah

Sebelum menjelaskan teknis penggunaan jarimatika, terlebih dahulu pengabdi memberikan pengenalan awal pada jarimatika yaitu memperkenalkan formasi jari tangan untuk perkalian masing-masing bilangan karena formasi jari tangan untuk perkalian 1 sampai 5 berbeda dengan formasi jari tangan untuk perkalian 6 sampai 9. Berikut perkenalan formasi jari tangan.

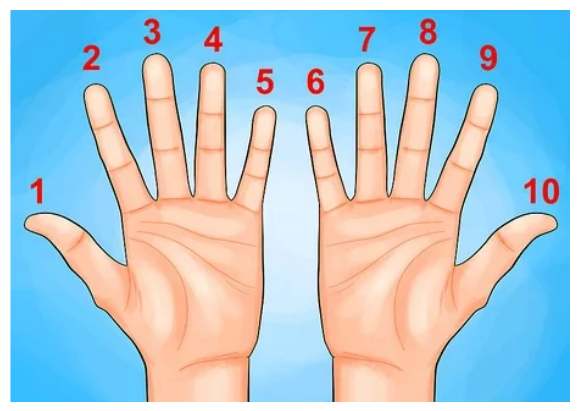

Gambar 2. Formasi Tangan untuk Perkalian 1-5 (Cara Mengalikan dengan Tangan, n.d.) 

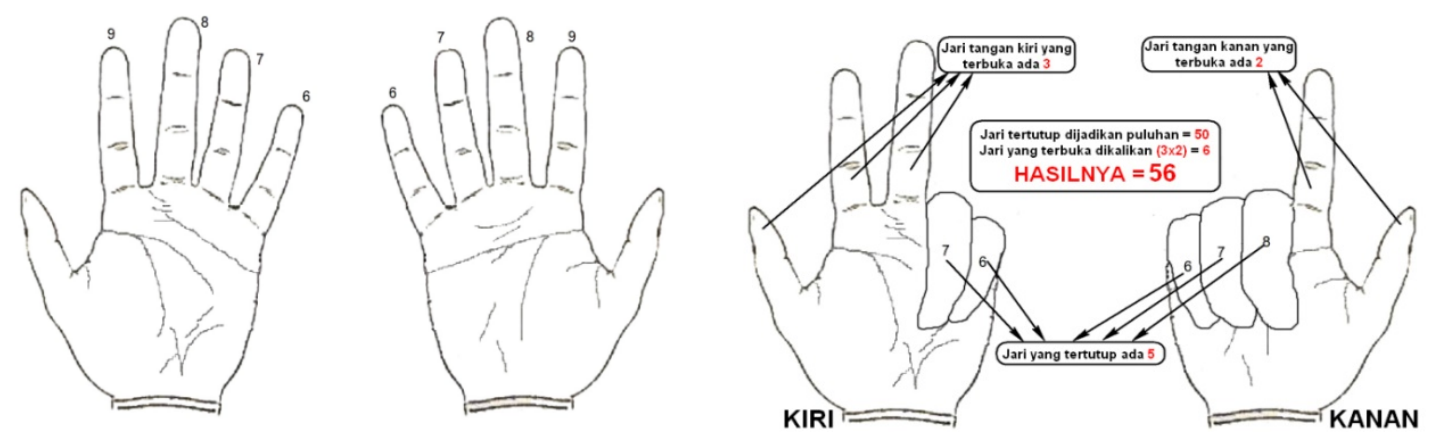

Gambar 3. Formasi Tangan untuk Perkalian 6-9

Materi pelatihan dijelaskan oleh tim pengabdi setelah memperkenalkan formasi jari tangan untuk masing-masing perkalian. Pengabdi terlebih dahulu menjelaskan aturan untuk perkalian 2 sampai 5 dengan memanfaatkan ruas-ruas jari. Setelah peserta dianggap mahir menggunakan jari tangan untuk perkalian sampai 5, selanjutnya pengabdi menjelaskan tentang aturan untuk perkalian 6 sampai 9 dengan menggunakan jari tangan. Selama kegiatan pelatihan berlangsung, pengabdi mendemonstrasikan cara menentukan hasil kali dua bilangan dengan menggunakan jari. Pengabdi memantau formasi jari dari masing-masing peserta didik dan mendampingi jika ada peserta yang bertanya atau kebingungan. Tim pengabdi berusaha membuat peserta didik mengikuti pelatihan dalam suasana yang santai dan tidak tegang serta semaksimal mungkin membuat peserta paham penggunaan jarimatika dalam menghafal perkalian dasar.
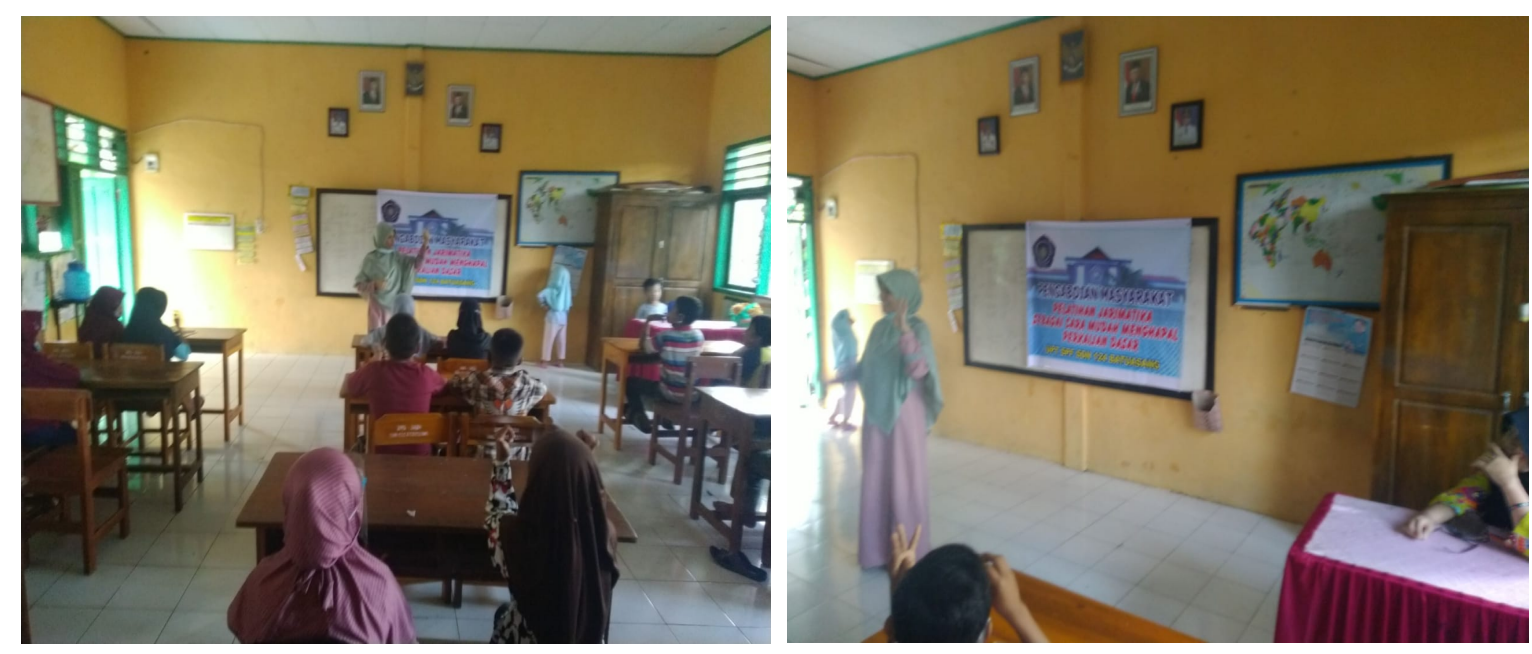

Gambar 4. Pengabdi memberikan Pelatihan Jarimatika

Pengabdi memberikan beberapa soal perkalian dasar untuk mengukur penguasaan peserta didik dalam menggunakan jarimatika. Kegiatan ini dilakukan setelah pemberian materi. Peserta didik antusias menjawab soal yang diberikan walaupun masih ada beberapa yang kadang masih bingung dengan formasi jarinya. Tetapi secara umum peserta didik hampir semuanya memahami jarimatika. Antusiasme mereka terlihat pada saat mereka meminta soal lagi kepada pemateri. 

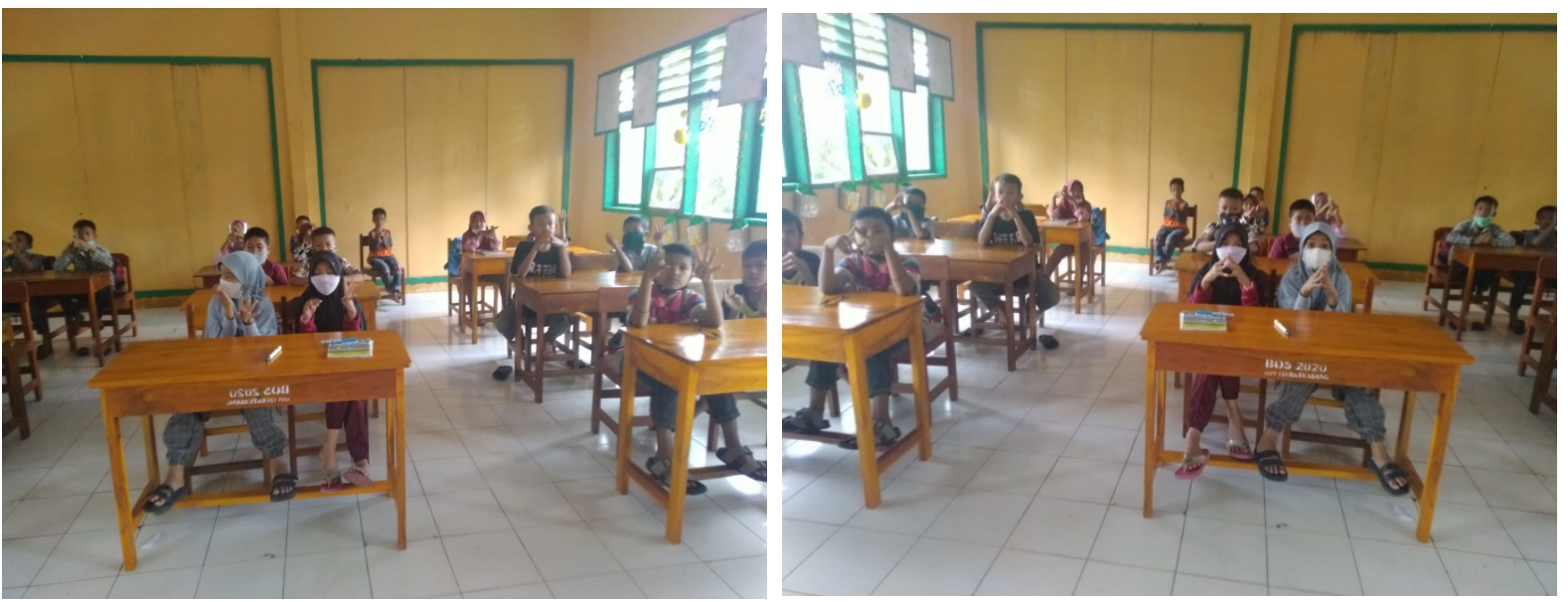

Gambar 4. Peserta Didik Mempraktikan Jarimatika

Kegiatan akhir yang dilakukan oleh tim pengabdi adalah membagikan angket respon peserta didik terhadap kegiatan pelatihan yang telah mereka ikuti. Adapun hasil analisis angket tersebut adalah sebagai berikut.

\begin{tabular}{|c|c|c|c|c|c|c|}
\hline \multirow{3}{*}{\begin{tabular}{l}
\multicolumn{1}{c}{ Pernyataan } \\
Cara menghitung \\
perkalian dengan \\
jarimatika
\end{tabular}} & \multicolumn{3}{|c|}{ Frekuensi } & \multicolumn{3}{|c|}{ Persentase } \\
\hline & Sulit & Mudah & $\begin{array}{l}\text { Sangat } \\
\text { Mudah }\end{array}$ & Sulit & Mudah & $\begin{array}{l}\text { Sangat } \\
\text { Mudah }\end{array}$ \\
\hline & 1 & 11 & 8 & $5 \%$ & $55 \%$ & $40 \%$ \\
\hline $\begin{array}{l}\text { Saat menghitung } \\
\text { perkalian dengan }\end{array}$ & $\begin{array}{l}\text { Tidak } \\
\text { Senang }\end{array}$ & Senang & $\begin{array}{l}\text { Sangat } \\
\text { Senang }\end{array}$ & $\begin{array}{l}\text { Tidak } \\
\text { Senang }\end{array}$ & Senang & $\begin{array}{l}\text { Sangat } \\
\text { Senang }\end{array}$ \\
\hline merasa & - & 11 & 9 & $0 \%$ & $55 \%$ & $45 \%$ \\
\hline $\begin{array}{l}\text { Menghitung } \\
\text { perkalian dengan }\end{array}$ & $\begin{array}{l}\text { Lebih } \\
\text { Cepat }\end{array}$ & $\begin{array}{l}\text { Sama } \\
\text { Saja }\end{array}$ & Lambat & $\begin{array}{l}\text { Lebih } \\
\text { Cepat }\end{array}$ & $\begin{array}{l}\text { Sama } \\
\text { Saja }\end{array}$ & Lambat \\
\hline jarimatika & 15 & 5 & 0 & $75 \%$ & $25 \%$ & $0 \%$ \\
\hline $\begin{array}{l}\text { Cara yang } \\
\text { digunakan pada }\end{array}$ & Menantang & $\begin{array}{l}\text { Menarik } \\
\text { \& Mudah }\end{array}$ & $\begin{array}{c}\text { Sulit } \\
\text { Dipahami }\end{array}$ & Menantang & $\begin{array}{l}\text { Menarik } \\
\text { \& Mudah }\end{array}$ & $\begin{array}{c}\text { Sulit } \\
\text { Dipahami }\end{array}$ \\
\hline ini lebih & 6 & 14 & 0 & $30 \%$ & $70 \%$ & $0 \%$ \\
\hline
\end{tabular}

Tabel 1. Respon Peserta Didik terhadap Pelatihan Jarimatika

Berdasarkan Tabel 1, terlihat bahwa pada umumnya peserta didik memberikan respon yang positif terhadap pelatihan jarimatika ini. Beberapa peserta didik menganggap bahwa jarimatika merupakan cara yang menantang untuk menentuka hasil perkalian dasar. Selain itu $75 \%$ peserta didik berpendapat bahwa menghitung perkalian dengan menggunakan jarimatika jauh lebih cepat.

\section{Kesimpulan}

Kegiatan pelatihan jarimatika untuk peserta didik kelas IV sampai kelas VI pada UPT SPF SDN 124 Batuasang membuat peserta pelatihan antusias mempelajari matematika. Kegiatan ini terlaksana dengan baik dan diikuti sebanyak 20 peserta didik. Dari hasil seluruh rangkaian kegiatan ini dapat disimpulkan bahwa: (1) peserta didik memahami formasi jari tangan dan aturan perkalian dengan menggunakan jarimatika; (2) 
peserta didik merasa lebih mudah dan lebih cepat dalam menghitung perkalian dasar dengan menggunakan jarimatika; (3) peserta didik memberikan respon positif terhadap kegiatan pelatihan ini. Secara umum kegiatan ini memberikan pengetahuan baru kepada peserta didik tentang salah satu metode cepat dan menyenangkan untuk menghafal perkalian dasar. Berdasarkan hal tersebut tim pengabdi menyarankan kepada guru-guru untuk memperkenalkan metode jarimatika sebagai salah satu alternatif untuk menghafal perkalian dasar. Untuk kegiatan pengabdian selanjutnya, Tim pengabdi memberikan rekomendasi agar melaksanakan pelatihan jarimatika bagi guru-guru.

\section{Ucapan Terimakasih}

Kegiatan pelatihan ini dapat terlaksana dengan baik berkat adanya dukungan dan kerja sama serta partisipasi dari berbagai pihak. Oleh karena itu tim pengabdi mengucapkan terimakasih banyak kepada Lembaga Penelitian Pengembangan dan Pengabdian kepada Masyarakat (LP3M) Universitas Muhammadiyah Makassar yang telah memberikan fasilitas dalam pelaksanaan kegiatan, terimakasih kepada Dekan FKIP dan Ketua Prodi Pendidikan Matematika Universitas Muhammadiyah Makassar, kepada Kepala Sekolah UPT SPF SDN 124 Batuasang selaku mitra, guru dan peserta didik UPT SPF SDN 124 Batuasang, serta seluruh pihak yang membantu dan berpartisipasi dalam kegiatan pelatihan ini.

\section{Referensi}

Ardyfu. (2016, February 16). Menghitung perkalian 6,7,8,9 dengan metode jari (Jarimatika). Ardyfu. https://ardyfu.wordpress.com/2016/02/16/menghitungperkalian-6789-dengan-metode-jari-jarimatika/.

Jana, P., \& Rahmawan, A. D. (2019). Pendampingan Persiapan Ujian Nasional Berbasis Komputer Pada Siswa Sma Muhammadiyah 3 Yogyakarta. Jurnal Berdaya Mandiri. https://doi.org/10.31316/ibm.v1i1.298.

Jarimatika. (2021). In Wikipedia bahasa Indonesia, ensiklopedia bebas. https://id.wikipedia.org/w/index.php?title=Jarimatika\&oldid=18619303.

Rosa, A. (n.d.). Buku Jarimatika. Retrieved April 20, 2021, from https://www.academia.edu/32309734/Buku_Jarimatika.

Syah, Muhibbin. 2010. Psikologi Pendidikan Dengan Pendekatan Baru.Bandung:PT Remaja Rosdakarya.

Wulandani, peni septi. 2008. Jarimatika Perkalian. PT Kawasan Pustaka: Jakarta Selatan.

------, Cara Mengalikan dengan Tangan. (n.d.). wikiHow. Retrieved April 20, 2021, from https://id.wikihow.com/Mengalikan-dengan-Tangan 